\title{
BUKAN SEKEDAR PENGGAUNG (BUZZERS): MEDIA SOSIAL DAN TRANSFORMASI ARENA POLITIK
}

\author{
Wahyudi Akmaliah
}

\begin{abstract}
Abstrak
Artikel ini melihat kemunculan buzzers (penggaung) politik sekaligus influencer (subyek berpengaruh) di Indonesia pasca rejim Orde Baru dalam memproduksi informasi, mempengaruhi publik dan berdampak terhadap elektablitas tokoh politik yang mengajukan diri sebagai pemimpin dalam politik elektoral. Ada tiga pertanyaan yang diajukan; kekuatan struktur apa yang mempengaruhi perubahan sekaligus pergeseran arena politik dari mobilisasi massa turun ke jalan melalui keramaian kemudian menjadi ranah online? Bagaimana dampak perubahan lanskap tersebut seiring dengan kemunculan otoritas-otoritas baru dengan kehadiran penggaung politik sebagai sumber referensi pengetahuan yang menjadi preferensi pilihan warganet sekaligus mempengaruhi elektabilitas seorang calon dalam politik elektoral? Apa dampak ikutan yang muncul dalam ranah maya ini? Artikel ini berargumen bahwa kemunculan internet dan media baru, ditandai dengan kehadiran media sosial, setidaknya telah menggeser distribusi informasi pengetahuan yang sebelumnya mutlak digenggam oleh oligarki pemilik media lama (televisi, media cetak, radio). Pergeseran struktur media ini membawa dampak terhadap kemunculan otoritas-otoritas baru dengan kehadiran penggaung, yang sebelumnya hanya digunakan dalam ranah periklanan. Sebagai bagian dari agensi, otoritas baru ini membawa kepada dua wajah; kreativitas dalam mengkampanyekan gagasan dan aktivitas destruktif yang dapat memecah sensivitas solidaritas kebangsaan dan kenegaraan di level akar rumput.
\end{abstract}

Kata kunci: penggaung, politik, pilkada jakarta, pilpres, otoritas baru, media sosial 


\section{Pengantar}

PadabulanAgustus 2018, seorang teman berceritakepada saya. Ia mengungkapkan bahwa dirinya diminta oleh salah satu lembaga survei di Indonesia untuk menjadi salah satu penggaung politik untuk mendukung satu kandidat dalam pertarungan Pemilihan Presiden (Pilpres) tahun 2019. Memilih para penggaung untuk menjadi salah satu pengendali dan mempengaruhi wacana publik sosial dan politik di Indonesia ternyata menjadi salah satu agenda yang dimainkan oleh lembaga survei di Indonesia terkait dengan upaya untuk memenangkan calon pemimpin, di mana lembaga tersebut diusung sebagai tim konsultan. Setelah melihat jumlah pengikutnya (followers) di media sosial, ia tidak batal dilibatkan. Dengan jumlah pengikut 11.000, ia dianggap tidak representatif sebagai penggaung politik. Menurutnya, seseorang layak dianggap penggaung politik jikalau pengikut yang dimilikinya minimal berjumlah 40.000. Padahal, sebagaimana diakuinya, untuk memiliki jumlah pengikut tersebut tidaklah mudah. Ketidakmudahan ini tampaknya dipengaruhi oleh karakter dirinya yang tidak mau melakukan beberapa hal yang menjadi prasyarat menanjaknya tambahan pengikut, seperti intensitas, provokasi, bertengakar di media sosial (twitwar), dan menyerang seseorang.

Pernyataan teman saya ini sebenarnya mengisyaratkan tiga hal penting terkait dengan pergeseran keterlibatan politik, termasuk kampanye, dari mobilisasi keramaian (offline) menuju dunia virtual (online) seiring makin signifikan penggunaan media sosial di Indonesia. Pertama, perubahan platform mobilisasi politik. Sebelumnya, sejak rejim Orde Baru berkuasa dan awal Reformasi, pengerahan massa memiliki konotasi dengan keramaian, mulai dari raungan knalpot sepeda motor, mobil hias, parade paramiliter, dan orasi para pembicara. Hal ini digunakan untuk mendukung calon pemimpin baik dalam Pemilihan Kepala Daerah (Pilkada) ataupun Pemilihan Presiden (Pilpres). Namun, mobilisasi dengan keramaian tersebut meredup digantikan dengan platform digital, di mana media sosial memiliki arena baru dalam pertarungan politik dalam berkampanye dan mempengaruhi publik pemilih. Kedua, munculnya distribusi kekuasaan media yang tidak tunggal. Kehadiran media sosial dengan munculnya penggaung baik secara individu maupun kelompok dengan munculnya platform digital media sosial seperti facebook, twitter, instagram, dan Youtube memang tidak mengubah peta oligarki kepemilikan media, baik cetak, radio, ataupun televisi, sehingga dengan mudah bisa menyampaikan kepentingannya melalui pemberitaan yang dibuat dan disampaikan. Namun, kehadiran dua faktor tersebut menciptakan distribusi informasi yang beragam 
dan bisa disampaikan secara langsung dan memungkinkan untuk bisa massif dan tersebar kepada sebagian besar warganet. Ketiga, tsunami informasi dalam telepon genggam. Kemunculan individu dan kolektif dengan menjadi penggaung yang memungkinkan mereka untuk membuat dan menyebarkan informasi ini membuat warganet menerima beragam informasi silih berganti dengan cepat, membuatnya menjadi kesulitan untuk membedakan mana yang benar dan bohong.

Tiga hal tersebut yang mempengaruhi dua momentum politik elektoral di Indonesia, yaitu Pilpres 2014 dan Pilkada Jakarta 2017. Dalam Pilpres 2014, misalnya, pertarungan antara Jokowi-JK dan Prabowo-Hatta menggunakan media sosial sebagai agitasi politik mempengaruhi publik pemilih, yaitu Twitter dan Facebook. Masing-masing tim pemenangan dan pendukungnya memiliki kekuatan di arena media sosial yang berbeda, di mana jumlah pengikut mempengaruhi tingkat dukungan dan keramaian dalam mempengaruhi wacana di ranah online. Melalui Twitter, dukungan terhadap salah satu calon diperlihatkan dengan menggusung tagar (\#). Tim pemenangan dan pendukung Jokowi menggunakan Twitter secara massif untuk menyatakan sikap politik sekaligus bagian dari sosialisasi dukungan politik. Hal ini terlihat dengan munculnya sejumlah tagar untuk mendukung Jokowi-JK yang kemudian menjadi trending topic, mulai dari \#TegasPilih2, \#JokowiJK_adalahKita, \#Salam2Jari, \#IndonesiaHebat_ekonomikuat, \#Nomor2Tegas, \#TegasPilih2, dan \#Salam2 dalam bulan Juni 2014. Dibandingkan dengan akun Prabowo dengan jumlah 905.000 pengikut, jumlah pengikut Jokowi jauh lebih banyak, yaitu 1, 62 juta pengikut (www.kompas.com, 24 Juni 2014).

Untuk Facebook, laman Prabowo melampaui laman Jokowi, di mana jumlah like yang menandakan pengikutnya berjumlah lebih dari 7 juta orang, sementara Jokowi lebih dari 3 juta. Meskipun demikian, terkait dengan kemunculan grup dukungan di facebook, pendukung Jokowi jauh semarak. Misalnya, untuk mendukung Jokowi, setidaknya ada 17 grup Facebook, yaitu "Jokowi Presiden", "Jokowi”, Rakyat Pendukung Joko Widodo", "Seknas Jokowi”, ”Jokowi-JK”, "Kenapa Jokowi", ”Jokowi for Indonesia”, ”Jokowisme”, ”Jokowi Blusukan", "Bara Jokowi Presiden”, ”Jokowi Mania”, "Seknas Tani Jokowi”, ”Jokowikami”, "Seknas Perempuan Pendukung Jokowi", "Relawan Jokowi-JK Sumbar", ”Jokowi Jusuf Kalla”, ”Jokowi Aksi”, "Presidenku Jokowi”, "Kawan Jokowi", "Koordinator Nasional Relawan Jokowi", dan "Relawan Pendukung Jokowi". Sementara itu, kubu Prabowo ini relatif sepi, hanya tiga grup, yaitu "Gardu Prabowo", "Relawan Prabowo", dan "Kawan Prabowo" (www.kompas.com, 24 
Juni 2014). Di sini, meskipun Jokowi-JK dan pendukungnya menguasai dunia maya dengan basis kelas menengah yagn mendukungnya, tapi efek destruktif kampanye negatif justru menimpa mereka. Sebagaimana diungkapkan oleh Politicawave, situs yang menjaring percakapan di media sosial, Jokowi-JK lebih banyak menjadi sasaran kampanye hitam dengan jumlah persentase 94,9\% dan 5,1\% kampanye negatif. Sementara itu, kampanye hitam bagi pasangan Prabowo-Hatta lebih sedikit yaitu 13,5\%, sementara kampanye negatifnya mencapai 86,5\%. Dalam ranah offline, penyebaran majalah Obor Rakyat juga menjadi bagian kampanye hitam untuk menurunkan elektabilitas Jokowi (Lestari, 2014).

Sebenarnya, pembahasan media sosial dan politik sudah dibahas oleh para sarjana, baik Indonesia maupun internasional. Dengan memfokuskan kepada akun-akun yang digunakan oleh partai politik di Indonesia, Abdillah (2014) dengan optimis melihat munculnya trend kampanye politik dengan menggunakan media sosial untuk memenangkan pemilu legislatif; sebuah cara yang kreatif sekaligus positif untuk menggaet para pemilih kelompok kelas menengah dan anak muda. Lebih jauh, Chen dan Priamarizki (2014) berpendapat bahwa media baru ini memungkinkan menjadi daya pengungkit lebih jauh untuk pilihan politik bagi para pemilih selama Pemilu Legislatif 2014 dan Pemilihan Presiden. Sebelumnya, Nugroho dan Syarief (2012) beranggapan bahwa media baru dan proses politik yang berlangsung itu menguatkan wacana perdebatan dalam masyarakat sipil di Indonesia. Lebih komprehensif, Johansson (2016) melengkapi pertautan media sosial dan politik tersebut dengan melihat artikulasi yang dimainkan oleh pelaku politik dengan menggunakan media sosial tidak hanya semata-semata sebagai proses bagian kampanye melainkan keterlibatan terhadap isu politik terbaru. Namun, dibandingkan dari para sarjana tersebut, tidak ada yang membahas bagaimana media sosial dijadikan medium s kampanye hitam melalui penyebaran ujaran kebencian. Dengan melakukan perbandingan kepada sejumlah situs, pemilik akun media sosial, sekaligus praktik jaringan analisis sosial (social network analysis), Lim (2017) mengamati ujaran kebencian tersebut dengan menjadikan kasus Pilkada DKI Jakarta 2017 sebagai contoh.

Melanjutkan studi Lim tersebut, artikel ini melihat kemunculan penggaung politik dalam politik di Indonesia dalam memproduksi informasi, baik itu positif ataupun negatif, yang mempengaruhi elektablitas calon yang mengajukan diri sebagai pemimpin baik sebagai kepala daerah ataupun presiden. Ada tiga pertanyaan yang diajukan dalam artikel ini; kekuatan 
struktur apa yang mempengaruhi perubahan sekaligus pergeseran arena politik dari mobilisasi massa turun ke jalan melalui keramaian kemudian menjadi ranah online? Bagaimana dampak perubahan lanskap tersebut seiring dengan kemunculan otoritas-otoritas baru dengan kehadiran penggaung politik sebagai sumber referensi pengetahuan yang menjadi preferensi warganet sekaligus mempengaruhi elektabilitas seorang calon, baik dalam Pilkada ataupun Pilpres? Apa dampak ikutan yang muncul dalam ranah maya ini? Artikel ini berargumen bahwa kemunculan internet dan media baru yang ditandai dengan kehadiran media sosial setidaknya telah menggeser distribusi informasi pengetahuan yang sebelumnya mutlak digenggam oleh oligarki pemilik media lama, baik itu televisi, media cetak, sekaligus radio. Pergeseran struktur media ini membawa dampak terhadap kemunculan otoritas-otoritas baru seiring dengan kehadiran para penggaung, yang sebelumnya hanya digunakan dalam ranah periklanan. Sebagai bagian dari agensi, otoritas baru dengan penggaung ini membawa kepada dua wajah; positif dan negatif. Secara positif, mereka memberikan perspektif kritis kepada warganet terkait informasi penting yang dapat dicerna sebelum menjatuhkan pilihannya di bilik suara. Secara negatif, media sosial bisa digunakan mereka untuk kampanye hitam, baik melalui ujaran kebencian ataupun berita bohong (hoax).

\section{Definisi dan Pergeseran Penggaung (Buzzers)}

Kata buzzers berasal dari bahasa Inggris. Dalam kamus elektronik Cambridge (2018), hal itu diartikan sebagai seperangkat alat elektronik yang membikin suara berdengung. Maksud berdengung di sini, lebih merujuk seperti lebah. Untuk konteks Indonesia, Anitasari (2017) mempadankan terma itu sebagai kentongan, alat tradisional, terbuat dari kayu, khususnya bambu di mana ada lubang memanjang di tengahnya. Ketika dipukul menggunakan gagang kayu makan akan menghasilkan bunyi. Alat ini biasanya digunakan untuk mengumpulkan warga untuk memberitahu informasi penting ataupun mengenai sebuah peristiwa. Sementara itu, Majalah Mingguan Tempo (2016) lebih mengartikan kata tersebut sebagai penggaung, di mana saya kemudian menggunakan kata tersebut dari awal hingga akhir tulisan. Dalam praktek platform digital, fenomena penggaung awalnya ini diadaptasi dari teori difusi inovasi, yaitu menjelaskan sosok komunikator atau pembawa pesan, yang mendapatkan informasi dari media massa. Informasi ini yang kemudian digunakan untuk mempengaruhi orang sekitarnya (Gunawan dan Salamah, 2018: 515). Tentu saja, definisi penggaung ini tumbuh seiring dengan kemunculan media baru, dalam hal ini digunakan dalam Twitter, yang didirikan San Fransisco, Amerika 
Serikat pada 21 Maret 2006 oleh Jack Dorsey, Noah Glass, Biz Stone, dan Evan Williams.

Istilah penggaung ini awal mula digunakan dalam periklanan oleh korporasi. Istilah itu digunakan pada tahun 2012, tiga tahun setelah Twitter hadir di Indonesia. Kehadiran penggaung untuk memperkenal produk barang ini digunakan ketika fitur dalam perangkat media sosial, baik Twitter dan Facebook belum ada. Munculnya istilah penggaung yang memiliki asosiasi dengan periklanan ini tercermin dari sejumlah pemberitaan media online, memberitakan pada tahun sesudahnya, 2013. Salah satu media online yang memberitahukan tersebut adalah Kompas.com. Dengan judul Di Indonesia, "Buzzers" Jadi Orang Bayaran, pada 27 Agustus 2013, media online yang memiliki basis di media cetak terbesar nasional itu menjelaskan fenomena ini penggaung sebagai bagian dari ranah promosi barang. Dibandingkan dengan negara-negara lain, termasuk Amerika Serikat, definisi penggaung di Indonesia tidak sebatas selebriti nasional, melainkan juga orang-orang biasa yang memiliki jumlah pengikut (followers) yang banyak. Karena itu, Reuters mengartikan penggaung di Indonesia tidak sebatas literal dalam bahasa Inggris, yaitu alarm atau lonceng, melainkan sebagai pengeruk uang bagi mereka yang memiliki akun Twitter dengan jumlah pengikut lebih dari 2000 orang. Melalui sekali cuitan untuk mempromosikan barang, seorang penggaung bisa menerima uang minimal 21 USD (Rp.250.00) (www.reuters.com, 23 Agustus 2013). Jumlah uang yang didapatkan ini tentu akan bertambah seiring dengan makin banyaknya jumlah pengikut yang dimiliki mereka.

Namun, definisi penggaung mengalami pergeseran makna dan tujuan sejak tahun 2014. Pada tahun tersebut partai politik banyak menggunakan jasa mereka untuk kampanye Pilpres 2014. Penggunaan penggaung untuk kepentingan politik ini mengubah definisi dan makna tersebut. Sebelumnya, ia memiliki konotasi positif, kemudian berubah menjadi cenderung negatif. Memang pada tahun 2012, khususnya Pilkada DKI, penggaung digunakan dalam politik, tapi maknanya masih cenderung positif seiring dengan belum maraknya kampanye hitam. Melihat fenomena ini, Camil, Attamimi, dan Esti (2017: 1012) mendefinisikan apa yang disebut dengan penggaung sekaligus karakter yang dimiliki. Menurut mereka, penggaung, baik individu ataupun kolektif adalah "individu atau akun yang memiliki kemampuan amplifikasi pesan dengan cara menarik perhatian dan/atau membangun percakapan dan bergerak dengan motif tertentu”. Dengan kata lain, masih menurut mereka, penggaung adalah pelaku yang "membuat suara-suara bising seperti dengung lebah". 
Secara karakter, setidaknya penggaung memiliki empat kemampuan. Pertama, persuasif. Dengan permainan kata dan narasi, seorang penggaung bisa membuat para pengikutnya membaca dan turut menyebarkannya. Kedua, jaringan yang luas. Jaringan ini bisa diartikan dua hal; jumlah pengikut yang dimilik, di mana semakin banyak maka memiliki daya amplifikasi. Ketiga, kemampuan memproduksi konten. Dalam hal ini mereka memiliki kemampuan tidak hanya mengemas informasi yang ramah secara visual, cakap menggunakan media sosial, dan mengerti ataupun memiliki latarbelakang jurnalistik. Keempat, digerakkan oleh motif tertentu. Maksudnya ada penggaung yang secara sukarela bergerak karena memang itu bagian dari visi personalnya. Ada juga mereka melakukan penggiringan opini politik sebagai sebuah pekerjaan yang dibayar.

Kehadiran penggaung ini tentu saja tidak hadir dengan sendirinya. Perubahan struktur media sebagai bagian dari komunikasi dan interaksi memiliki peranan signifikan. Di sini, faktor eksternal dan internal mempengaruhi perubahan tersebut yang ditandai dengan lalu lintas teknologi, barang, sekaligus orang, yang masuk dan keluar dari Indonesia. Kemunculan platform digital media baru harus diakui telah mengubah lanskap media di Indonesia, memungkinkan partisipasi publik secara lebih luas. Di bawah media lama (televisi, media cetak, dan radio), kontrol sepenuhnya berada di tangan pemilik modal. Meskipun demikian, saat rejim Orde Baru berkuasa, adanya sentralisasi kebijakan dan regulasi, memungkinkan untuk melakukan pengontrolan yang lebih ketat kepada media lama tersebut. Namun, kehadiran internet memberikan ruang setiap individu untuk menjadi bagian dari memproduksi dan menyebarkan gagasan dengan kemunculan World Wide Web sebagai penyedia data situs, di mana orang bisa membaca, mengakses dan kemudian mencetaknya kembali untuk disebarkan secara offline. Kehadiran generasi kedua internet yang disebut dengan Web 2.0, di mana pengguna bisa berjejaring dan menjadi produsen sekaligus konsumen secara bersamaan dengan kehadiran media sosial mengubah tatanan interaksi dan komunikasi yang digunakan oleh media lama sebelumnya.

Perubahan struktur ini memunculkan otoritas-otoritas pengetahuan baru melalui akun-akun media sosial. Dampaknya, genealogi pengetahuan, jejaring keilmuwan, dan otoritas yang disebut ahli mengalami penggerusan dalam media online. Dengan hanya berbekal pencarian Google, dengan latarbelakang yang berbeda, seseorang bisa disebut sebagai ahli agama. Mendapatkan informasi lebih dahulu mengenai isu politik, dengan kemampuan dan latarbelakang teknologi komputer, orang bisa didaulat sebagai pengamat politik. Ironisnya, otoritas-otoritas baru ini diterima begitu saja tanpa ada resistensi besar dari 
masyarakat. Kehadiran Jonru merupakan contoh kemunculan otoritas baru ini di media sosial. Berawal dari Pilpres 2014, ia mendukung Prabowo-Hatta. Tidak hanya melakukan agitasi politik, kebencian, dan menyebarkan hoax, ia menyerang Jokowi-JK selama Pilpres 2014 tersebut. Pasca Prabowo-Hatta kalah, sikap oposisi itu tidak berhenti, justru makin bertambah menguat, yang membuat jumlah pengikutnya bertambah sangat signifikan. Posisi sebagai oposisi Jokowi ini yang kemudian menjadi pekerjaan utamanya, di mana uang yang didapatkan adalah melalui promosi sejumlah barang dan jasa sekaligus juga bekersama dengan lembaga penerima sedekah membuat semacam crowd-funding untuk membantu pembangunan masjid di beberapa daerah di Indonesia serta membantu fakir miskin (Akmaliah, 2017). Pada titik ini, definisi penggaung kemudian lebih cenderung dimaknai kepada keterlibatan politik di media sosial dengan citra negatif.

\section{Signifikansi Media Sosial Dalam Sentimen Politik Elektoral}

Di tengah tumbuhnya pengguna internet dan media sosial di Indonesia yang semakin massif seiring dengan adanya demokratisasi harga telepon genggam dengan munculnya merek baru dari Republik Rakyat China, media online kemudian menjadi medan kampanye yang penting dalam politik elektoral. Hal ini tercermin kuat dalam Pilkada DKI 2017. Secara khusus, dalam edisi 28 November-4 Desember 2016, Tempo membuat edisi khusus mengenai fenomena ini yang menjadi wajah depan majalah mingguan tersebut dengan judul Perang Digital Pilkada Jakarta. Dalam Pilkada ibukota tersebut, ada tiga kandidat yang bertarung untuk memperebutkan orang nomor satu dan dua Jakarta, yaitu petahana Ahok-Djarot (Basuki Thahaja Purnama-Djarot Saiful Hidayat), Anies-Sandi (Anies Baswedan-Sandiago-Uno), dan Agus-Sylvi (Agus Harimurti Yudhoyono-Syilviana Murni). Masing-masing mereka membuat tim pemenangan, termasuk tim pemenangan media sosial untuk memperkenalkan para calonnya di dunia maya. Misalnya, melalui Hariadhi (anggota Jaringan Media Volunter/Jasmev) dan Eva Sundari, politikus PDIP, mereka berdua mengkordinasi tim bidang data dan informasi. Secara resmi ada tiga akun media sosial dan satu situs yang didaftarkan di KPU Jakarta, yaitu AhokDjarot untuk facebook, @AhokDjarot untuk Twitter, ahokdjarot untuk instagram, dan situs www.ahokdjarot.id. Memanfaatkan tim Pilkada DKI Jakarta pada tahun 2012 yang sebelumnya sudah terbentuk dalam media sosial, Hariadhi kemudian melatih secara serius 400 orang yang dijadikan relawan secara intensif. Mereka mendapatkan pelatihan bagaimana membuat video dan membangun narasi agar dapat mengundang warganet untuk tertarik melalui proses kampanye ini. 
Di bawah Roy Suryo sebagai Ketua Bidang Teknologi dan Informasi pemenangan Agus-Sylvi, mereka membentuk "Tim Cyber AHY” melalui Whatsapp Grup. Grup ini kemudian sebagai bentuk interaksi dan kordinasi mengenai kampanye Agus-Sylvi di media sosial dengan terbagi kepada tiga grup besar. Grup pertama terdiri atas empat ahli informasi teknologi dan grafis, dipimpin Raditya. Tim ini setiap hari melekat ke Agus. Grup kedua, Sandi Aditya, terdiri atas tiga orang, dan melekat ke Sylvi. Ketiga, tim langsung di bawah Roy Suryo yang berjumlah 4 orang. Kepada KPU Jakarta, mereka mendaftarkan empat akun sebagai kampanye di media sosial dan maya, yaitu akun Twitter@AgusSylviDKI, Instagram@AgusSylviDKI, Facebook AgusSylviForDKI1, dan situs http: // AgusSylviDKI.com. Mereka juga disokong oleh jejaring akun media sosial milik 167 relawan dan ratusan simpatisan lainnya. Sementara itu, Raditya Utama, kordinator tim media pasangan Anies-Sandi, membentuk Tim 13. Tim ini yang bertugas memasyaratkan 23 program Kerja Anies-Sandi di akun Facebook, Twitter, Instagram, YouTube, serta situs resmi pasangan yang diusung Partai Gerindra dan Partai Keadilan Sejahtera. Nama aku tersebut adalah AniesSandi di Facebook. Untuk twitter adalah@JktMajuBersama, @Aniesbaswedan, @ Suaraanies, @Relawananies, dan @sandiuno. Di instagram nama akun tersebut adalah@jakartamajubersama dan Jakarta Maju Bersama di YouTube. Mereka juga mengurus jakartamajubersama.com. Semua akun sudah didaftarkan ke Komisi Pemilihan Umum Jakarta (Tempo, 2016).

\begin{tabular}{|l|l|l|l|}
\hline $\begin{array}{c}\text { Media Sosial } \\
\text { dan Situs }\end{array}$ & \multicolumn{1}{|c|}{ Ahok-Djarot } & \multicolumn{1}{c|}{ Agus-Sylvi } & \multicolumn{1}{c|}{ Anies-Sandi } \\
\hline Facebok & AhokDjarot & AgusSylviForDKI1 & AniesSandi \\
\hline Twitter & @AhokDjarot & @AgusSylviDKI & $\begin{array}{l}\text { @JktMajuBersama, @Aniesbaswedan, } \\
\text { @Suaraanies, @Relawananies, @ } \\
\text { sandiuno. }\end{array}$ \\
\hline Instagram & ahokdjarot & @AgusSylviDKI & @jakartamajubersama \\
\hline Youtube & & & Jakarta Maju Bersama \\
\hline Situs & www.ahokdjarot.id & ww.AgusSylviDKI.com & www.jakartamajubersama.com \\
\hline
\end{tabular}

(Dioleh dari Majalah Tempo dan Kompas.com, 2016)

Akun dari ragam media sosial tersebut merupakan yang resmi didaftarkan di KPU Jakarta. sementara itu, yang tidak terdaftar oleh masing-masing kandidat, baik sebagai penggaung yang dibayar ataupun sukarela mempengaruhi secara signifikan untuk mengunggulkan masing-masing calonnya ataupun kemudian menyerang kandidat calon yang lain. Akun-akun yang tidak terdaftar dalam 
KPU ini memiliki tingkat signifikan yang sangat tinggi. Sebagaimana dicatat oleh Tempo dalam edisi tersebut, banyak dari akun-akun di Twitter, dengan beragam latarbelakang memainkan fungsinya. Ada yang terus mendukung calon yang diusung. Ada yang mendukung calon yang didukung dan kemudian menyerang calon lainnya. Ada yang khusus untuk menyerang calon lainnya. Selain terdiri dari tokoh politik, agama, dan masyarakat, tidak sedikit juga mereka adalah akun-akun anonim. Tingkat pola dukungan dan serangan ini masih dalam level aman dan tidak destruktif hingga munculnya tsunami melalui video editan Ahok 30 detik di Kepulauan Seribu yang diunggah oleh Buni Yani pada 6 Oktober 2016, dengan menghilangkan satu kata dalam transkripnya sehingga menjurus provokasi.

Dalam video, ungkapan Ahok itu "Dibohongi Pakai Surat Al-Maidah", menjadi "Dibohongi Surat Al-Maidah", di mana kata pakai kemudian dihilangkan. Berawal dari sini, sentimen yang sebelumnya begitu menguat kepada Ahok kemudian terjun bebas dan menjadi viral. Keberpihakan kepada Ahok atas kerja-kerja infrastruktur dan administrasi keadilan sosial langsung jungkir balik seiring dengan adanya kampanye hitam secara massif. Menurut catatan Political Wave, sebelum ada kasus Surat Al-Maidah, 23 September-5 Oktober 2016, nama Ahok dan Djarot paling banyak diperbincangkan dengan mendapatkan sentimen positif, yaitu 63, $81 \%$. Saat kasus terjadi, Ahok memang paling banyak dibicarakan tetapi dengan sentimen negatif menjadi 4,48 \%. Kondisi ini kemudian memberikan keuntungan kepada dua pasangan pesaingnya. Sebelumnya, Agus-Sylvi mendapatkan pembicaraan positif hanya 14,94\% kemudian naik menjadi 48,48\%. Anies-Sandi, sebelumnya mendapatkan pembicaraan positif 21, $25 \%$ menjadi 46, $68 \%$ (Tempo, 2016).

Kondisi ini kemudian berimbas di dunia nyata, di mana elektabilitas suara Ahok-Djarot turun dratis. Sebelumnya, dalam semua poll survei Ahok-Djarot menduduki peringkat pertama. Setelah kasus tersebut, elektabilitasnya kemudian berada diurutan kedua. Sebagaimana diungkapkan oleh Lingkar Survei Indonesia melalui hasil surveinya yang dilakukan pada 15-22 November 2016 kepada 798 respondon. Agus-Sylvi menempati urutan pertama sebesar 30,4 \%, kedua diikuti oleh Ahok-Djarot 26, $2 \%$, dan terakhir Anies-Sandi 24, $5 \%$. Dalam putaran pertama, Ahok-Djarot memang memenangkan perolehan suara, tapi pada putaran kedua justru mengalami kekalahan. Ini disebabkan karena tidak ada perubahan suara dari pendukung Agus-Sylvi untuk beralih ke Ahok-Djarot (Tempo, 2016). Sebaliknya, mereka justru mengalihkan suara kepada Anies-Sandi. Akibatnya, secara keseluruhan Anies- 
Sandi memperoleh 57,95 persen suara. Sementara itu, Ahok-Djarot meraih 42,05 persen. Kasus Surat Al-Maidah yang kemudian terjadi adanya mobilisasi massa dengan membangun sentimen Islam dan Non-Muslim menjadi penyebab peralihan dukungan tersebut. Kerja-kerja infrastruktur, reformasi administrasi pemerintahan, transparansi tata kelola pemerintahan yang baik melalui sistem terbuka, dan proses revitalisasi sungai-sungai Jakarta untuk menghindari banjir yang sebelumnya diterima dengan baik oleh masyarakat, dikalahkan oleh reproduksi kampanye hitam tersebut.

\section{Industri Penggaung Dalam Politik Elektoral}

Peralihan suara dan kekalahan Ahok-Djarot ini tidak tiba-tiba datang karena inisiatif individu dan kolektif. Di sini, media sosial dan reproduksi sentimen negatif dengan kampanye hoax memainkan peranan yang penting. Selain adanya bentuk mobilisasi melalui gerakan Aksi Bela Islam yang berjilid-jilid, juga adanya peranana para penggaung politik sehingga mempengaruhi secara signifikan menggerus suara Ahok-Djarot melalui sejumlah berita bohong. Untuk memfokuskan kepada pembahasan, saya tidak membahas lebih jauh para aktor politik di balik Aksi berjilid-jilid tersebut. Sebaliknya, di sini, saya membahas para penggaung politik tersebut yang kemudian menjadi industri, di mana mereka melakukan itu karena benar-benar mendapatkan bayaran sekaligus mereka dibayar sekaligus karena visi keyakinannya. Dua penggaung tersebut adalah Saracen dan Muslim Cyber Army (MCA). Kedua penggaung ini terbongkar oleh pihak kepolisian pasca Pilkada DKI Jakarta. Di sini, ada dua sasaran dari dua penggaung kolektif tersebut, yaitu isu PKI dan anti-Islam kepada presiden Jokowi dan Hoax dan Sara dalam Pilgub DKI Jakarta 2017.

Menurut Ensikloped Britania (2018), Saracen sendiri merupakan sebutan bagi orang Arab, Turki ataupun yang lainnya menyatakan diri sebagai bagian dari agama Islam yang tinggal di Semenanjung Sinai. Setelah itu, istilah tersebut kemudian digunakan oleh orang-orang Kristen untuk menyebutkan orang Arab secara umum. Setelah berdirinya kekhalifahan, Bizantium menyebut semua orang Muslim khalifah tersebut sebagai Saracen. Seiring dengan kemunculan tentara salib, nama tersebut kemudian menyebar ke Eropa Barat dan bertahan hingga abad modern. Nama itu yang kemudian digunakan oleh Jasriadi (Ketua), Faizal Muhammad Tonong (Ketua bidang media informasi), dan Sri Rahayu Ningsih (Koordinator wilayah) untuk menjual jasanya kepada para kliennya dengan harga kisaran antara Rp. 75 juta-100 juta rupiah melalui proposal yang diajukan. Layaknya bisnis jasa lainnya, pembuatan satu situs dihargai 15 juta. 
Untuk penggaung, di mana mereka memiliki 15 orang, mendapatkan upah selama sebulan sebesar Rp. 45 juta (www.liputan6.com, 26 Agustus 2017). Memang, dalam proses pengadilan, pihak kepolisian tidak bisa membuktikan mengenai transfer uang yang dilakukan oleh Jasriadi. Namun, reproduksi hoax yang dilakukan oleh sejumlah ribuan akun-akun anonim tidak bisa diabaikan begitu saja bahwasanya sindikasi hoax dalam politik elektoral itu ada.

Hal ini terlihat dengan adanya penangkapan selanjutnya yaitu the family of Muslim Cyber Army pada Februari 2018, setahun sesudahnya. Berbeda dengan Saracen yang lebih memiliki unsur bisnis dan memiliki struktur kepengurusan yang sistematis dan ada di pelbagai daerah, MCA ini organisasinya bersifat cair dan terdiri dari ribuan anggota serta bersifat terbuka. Meskipun awalnya bersifat terbuka, jaringan online ini kemudian mengerucut menjadi lebih kecil dengan nama Family Muslim Cyber Army. Awal berdirinya MCA ini sebenarnya berawal dari sebuah pengumuman di Facebook akhir tahun 2016 yang mengajak masyarakat untuk bergabung dalam melakukan pelatihan yang disebut dengan "gathering". Pelatihan ini tidak gratis. Per orang diharuskan membayar sejumlah uang tergantung kelas yang akan diikuti. Klasifikasinya dibagi menjadi tiga kelas, yakni kelas terendah Rp.250.000, kedua Rp.500.000, dan yang paling mahal adalah Rp.750.000. Peminatnya sangat membludak. Menurut amatan CNNIndonesia.com pada saat hari pelaksanaan, Sabtu 31 Desember 2016, Masjid WTC Jenderal Sudirman, Karet, Setiabudi, Jakarta Selatan yang digunakan sebagai basis pertemuan saat itu benar-benar penuh disesaki peserta. Barisan perempuan maupun laki-laki tak jauh berbeda, sama-sama mengular. Sepanjang acara, peserta diajak melantunkan atau mendengarkan pembacaan ayat Al-Quran, makan bersama, atau mendengarkan ceramah dan ajaran dari Jonru yang memang menjadi pembicara kunci (keynote speaker) saat itu (www. cnnindonesia.com, 2 Maret 2018).

Dalam pelatihan tersebut, peserta juga berlatih cara menge-twit dan membikin status-status menarik di media sosial, layaknya pelatihan copywriter. Alih-alih menggunakan mesin canggih dengan teknologi mutakhir, dalam pelatihan ini peserta hanya diperkenalkan dengan media sosial. Aktivitas ini yang kemudian disebut dengan jihad yang sekaligus diklaim bisa menghasilan uang. Para peserta yang sudah membayar ratusan ribu itu kemudian diajak berjanji untuk "berjihad" melalui media digital. Meskipun Jonru sendiri tidak menjelaskan lebih detail bagaimana mendapatkan uang dari media sosial tersebut (www. cnnindonesia.com, 2 Maret 2018). Namun, jika diamati pola kerja yang selama ini digunakan oleh Jonru melalui akun facebook dan page-nya, ia 
bekerja dengan cara memfitnah dan membikin hoax sehingga memungkinkan dirinya menambah pengikut. Saat pengikutnya telah banyak, ia kemudian menawarkan jasa promosi melalui akunnya tersebut. Dengan kata lain, Jonru melakukan tindakan fitnah yang disebutnya sebagai keyakinan berjihad dengan mengkapitalisasi kebencian para pendukung anti-Jokowi. Banyaknya jumlah status facebook yang dibagi (sharing), yang menyukai (like) sekaligus pengikut (followers) menjadi modal utama untuk menawarkan jasa promosi (Akmaliah, 2017).

Tentu saja, reproduksi hoax dan kemudian menjadi viral tersebut tidak akan bergerak secara massif tanpa adanya struktur dan mesin yang mengamplifikasinya secara luas sehingga menjadi sebuah kebenaran tanpa adanya proses untuk memilih dan memilah. Di sini rejim algoritma yang digunakan oleh media sosial memiliki pengaruh yang cukup kuat atas tersebarnya hoax tersebut. Sebagaimana diketahui, algoritma media sosial digunakan untuk mengetahui kecenderungan dari pengguna atas informasi yang dicari, disukai, dan kemudian disebarkan. Dengan mengetahui pola ini, algoritma kemudian mengarahkan kita kepada sesuatu yang kita lebih sukai. Pola kecenderungan dengan rejim algoritma ini menjadi bermasalah ketika ini bersentuhan dengan politik elektoral, dalam konteks ini adalah pemilihan presiden pada tahun 2014 yang hanya menggusung dua calon yang saling bersaing Jokowi versus Prabowo. Apabila teman facebook kita menyebarkan berita bohong dan kemudian kita mengklik lalu membacanya, algoritma facebook akan mengarahkan kita dengan informasi-informasi tersebut. Di sisi lain, alih-alih memiliki tradisi membaca yang kuat, masyarakat Indonesia tumbuh dengan tradisi oral, di mana berbicara dan bergosip kemudian menjadi dua aktivitas yang seringkali tidak dapat terpisahkan. Akibatnya, ketika ada berita hoax yang menyebar, orang tidak memiliki kemampuan untuk menyeleksi lebih detail atas informasi yang masuk sehingga diterima begitu saja sebagai sebuah kebenaran. Di sini, reproduksi hoax yang dianggap kebenaran ini kemudian menjadi senjata yang cukup artikulatif untuk menggerogoti kredibilitas lawan-lawan politiknya.

Dalam konteks Pilkada Jakarta, sebagaimana dilansir oleh liputan the Guardian, tim pemenangan Ahok sendiri menggunakan jasa tim penggaung. Hal ini diungkapkan sendiri oleh Alex bersama dengan dua puluh orang lainnya yang tergabung dalam Cyber Army untuk menangkal sejumlah hoax yang menimpa Ahok sekaligus melakukan proses reproduksi hoax untuk mendukungnya. Bersama teman-temannya tersebut, Alex dibayar perbulan masing-masing 280 USD atau sekitar Rp.4 juta. Mereka sehari memposting 60-120 kali melalui 
akun Twitter dan Facebook palsu mereka (www.theguardian.com, 23 Juli 2018). Namun, dengan posisi Ahok sebagai minoritas ganda di Indonesia; Tionghoa dan Kristen reproduksi hoax yang terus dilakukan tidak akan mampu membendung arus tsunami hoax yang dipropagandakan oleh MCA dan kemudian direproduksi terus-menerus oleh sejumlah tokoh agama dan elit politik di Indonesia agar pemerintah Indonesia mengadilinya untuk di penjara terkait dengan kasus surat Al-Maidah. Apalagi, apa yang dilakukan oleh MCA ini bagian dari jihad untuk membela Islam dengan legitimasi Surat Al-Maidah yang dilecehkan, membuat perlawanan melalui kampanye hitam dan kebencian menjadi semakin menguat di tengah kebijakan presiden Jokowi yang tidak merangkul kelompok-kelompok Islam konservatif dalam pemerintahannya sebagaimana dilakukan oleh Soesilo Bambang Yudhoyono selama dua periode pemerintahannya (2004-2009 dan 2009-2014).

\section{Kesimpulan}

Artikel ini menjelaskan bagaimana media sosial digunakan dalam politik elektoral. Alih-alih sekedar sebagai kampanye untuk menggunggulkan calonnya sebagaimana lumrah terjadi dalam politik elektoral, kehadiran media sosial melampaui dari sekedar kampanye positif. Sebaliknya, media sosial digunakan menyerang dan menghantam lawan-lawan politiknya dengan informasi negatif yang masih terbilang sehat seiring dengan kemunculan para penggaung yang sebelumnya digunakan sekedar sebagai promosi barang. Namun, permintaan penggaung yang semakin menguat dan dapat mempengaruhi elektabilitas seseorang seiring dengan makin banyaknya pengguna media sosial di Indonesia dan adanya demokratisasi telepon genggam murah dari Republik Rakyat China, penggaung makin dibutuhkan dan menjadi industri. Dalam konteks ini, secara individu orang bisa tergabung dalam tim cyber untuk pemenangan calon tertentu dalam politik elektoral, sebagaimana digunakan oleh tim pemenangan Ahok sekaligus juga musuh-musuh politiknya sebagaimana digunakan oleh Saracen.

Namun, reproduksi hoax yang menggunakan isu sara di tengah kuatnya tradisi oral, hal itu sangat berbahaya terhadap bangunan solidaritas keindonesiaan. Pilkada Jakarta adalah cermin, bagaimana isu hoax yang digunakan oleh MCA dan kemudian direproduksi oleh masyarakat kemudian dianggap sebagai bagian dari jihad dalam politik elektoral. Akibatnya, kondisi ini makin membelah masyarakat Indonesia menjadi dua kubu, antara pendukung atau melawan. Di sisi lain, imajinasi keindonesiaan dan keragaman yang terus dinarasikan menjadi 
titik pijak yang dilemahkan dengan adanya hoax semacam ini. Runtuhnya rejim Orde Baru dan adanya pilkada langsung dengan adanya otonomi daerah sebagai buah reformasi memberikan harapan generasi bangsa untuk membangun Indonesia. Di sini, tunas-tunas muda Indonesia bisa memberikan harapan menjadi pemimpin bangsa yang memutus mata rantai keburukan yang dilakukan oleh rejim Orde Baru. Kehadiran Ahok merupakan buah dari sistem reformasi ini. Namun, politik sara dengan memainkan hoax dan kebencian di media sosial melalui reproduksi informasi palsu para penggaung, baik individu maupun kolektif menggugurkan mimpi-mimpi itu. Ironisnya, kehadiran media sosial dan internet dengan kehadiran MCA justru menguatkan kembali imajinasi primordial yang justru saat Indonesia merdeka merupakan prasyarat untuk dihapuskan atas nama kesetaraan bangsa Indonesia.

Kehadiran hoax semacam ini menimpa tidak hanya Indonesia melainkan juga negara maju seperti Amerika Serikat dan Inggris, pemilik media sosial kemudian membuat regulasi baru untuk membasmi hal tersebut. Facebook, misalnya, kemudian menerapkan regulasi baru dengan adanya fake news yang mencoba mengabarkan atas informasi yang tidak benar dan terdapat kebohongan. Meskipun demikian, efek dari industri penggaung itu tidak bisa dihilangkan, apalagi ini beririsan dengan politik elektoral yang memiliki efek langsung kepada masyarakat Indonesia. Di sini, tagar \#2019gantipresiden merupakan wajah baru ikutan dari industri penggaung sebelumnya. Tagar ini yang terus direproduksi melalui media sosial. Titik perbedaan dari sebelumnya adalah tagar ini bergerak dari online menuju offline dan kemudian online-offline itu digunakan aktivitasnya secara bergantian. Selain memiliki motif ideologi yang cenderung kepada gerakan Islamisme, gerakan tagar ini ingin menggerogoti elektabilitas Jokowi. Meskipun demikian, efek negativas dan destruksinya terlihat mirip dengan Pilkada Jakarta. Karena itu, untuk melanjutkan studi ini, tagar ganti presiden merupakan proses lanjutan studi yang bisa dilakukan oleh para sarjana lain untuk mengisi kekurangan studi yang saya telah lakukan ini. 


\section{Daftar Pustaka}

Abdillah, Leon Andretti. "Social Media as Political Party Campaign in Indonesia”, Jurnal Ilmiah MATRIK Vol.16 No.1, April 2014:1 -10.

Akmaliah, Wahyudi. "Hikayat Jonru: Dari Cerpenis higga Peternak Kebencian", Geotimes, 7 Oktober 2017, dikutip dari https://geotimes.co.id/kolom/ sosial/hikayat-jonru-dari-cerpenis-hingga-peternak-kebencian-1/, pada 5 September 2018.

Anitasari, Nurarini. "Mengenal Pengertian Buzzers Pada Media Sosial", Zahira Accounting, 14 Juni 2017, dikutip dari https://zahiraccounting.com/id/blog/ pengertian-buzzer-pada-sosial-media/, pada 5 September 2018.

Anonim. "Buzzer", Cambridge Dictionary, 10 September 2018, dikutip dari https://dictionary.cambridge.org/dictionary/english/buzzer, pada 10 September 2018.

Anonim. "Di Indonesia Buzzer Jadi Orang Bayaran”, Kompas.com, 27 Agustus 2017, dikutip dari https://tekno.kompas.com/read/2013/08/27/0912097/ Di.Indonesia.Buzzer.Jadi.Orang.Bayaran, pada 2 September 2018.

Anonim. "I felt disgusted': inside Indonesia's fake Twitter account factories", The Guardian, 23 Juli 2018, dikutip dari https://www.theguardian.com/ world/2018/jul/23/indonesias-fake-twitter-account-factories-jakartapolitic, pada 10 September 2018.

Anonim. "In Indonesia, Buzzers Are not heard, but tweet for money", Reuters, 23 Agustus 2013, dikutip dari https://www.reuters.com/article/ net-us-indonesia-twitter/in-indonesia-buzzers-are-not-heard-but-tweet-for-moneyidUSBRE97L14T20130822, pada 3 September 2018.

Anonim. "Memantau Kicauan Para Buzzer Paslon Jelang Debat Pilgub DKI", Tirto.id, 27 Januari 2017, dikutip dari https://tirto.id/memantau-kicauanpara-buzzer-paslon-jelang-debat-pilgub-dki-chNz, pada 3 September 2018.

Anonim. "Muslim Cyber Army, Bujuk Rayu Jihad dan Cari Duit dari Medsos", CNN Indonesia, 2 Maret 2018, dikutip dari https://www.cnnindonesia. com/nasional/20180302101629-20-279882/muslim-cyber-army-bujukrayu-jihad-dan-cari-duit-dari-medsos, pada 10 September 2018.

Anonim. "Pertarungan Pilpres Sengit di Medsos", BBC Indonesia, 5 Juli 2014, dikutip dari https://www.bbc.com/indonesia/berita_ indonesia/2014/07/140704_pilpres_medsos, 4 September 2018.

Anonim. "Politik di Era Industri Buzzer", Tirto.id, 2 November 2017, dikutip dari https://tirto.id/politik-di-era-industri-buzzer-czqF, pada 10 September 2018.

Anonim. "Semarak Media Sosial Selama Pilpres", Kompas.com, 24 Juni 2014, dikutip dari https://nasional.kompas.com/read/2014/06/24/0245002/ Semarak.Media.Sosial.Selama.Pilpres, pada 2 September 2018. 
Anonim. "Siapa Pemesan Sindikat Saracen?", Liputan6.com, 26 Agustus 2017, dikutip dari https://www.liputan6.com/news/read/3071612/siapapemesan-sindikat-saracen, pada 10 September 2018.

Britanica. "Saracen”, Britanica, 2018, dikutip dari https://www.britannica. com/topic/Saracen, pada 10 September 2018.

Camil, Rinaldi, Natasha Hassa, and Klara Esti. "Dibalik Fenomena Buzzers: Memahami Lanskap Industri dan Pengaruh Buzzer di Indonesia”, Center for Innovation Policy and Governance, 2017.

Chen, Jonathan and Adhi Priamarizki. "Popular Mandate and the Comingof-Age of Social Media's Presence in Indonesia Politics Post-Reformasi", S. Rajaratnam School of International Studies Working Paper No. 268, 18 February 2014.

Johansson, Anders C. "Media Social and Politics in Indonesia”, Stockholm School of Economics Asia Working Paper No. 42 December 2016.

Lim, Merlyna. "Freedom to hate: social media, algorithmic enclaves, and the rise of tribal nationalism in Indonesia", Critical Jounal of Asian Studies, Volume 49, 2017-Issue 3.

Nugroho, Yanuar \& Sofie Shinta Syarief. "Beyond Click-Activism? New Media and Political Processes in Contemporary Indonesia", Berlin: Fesmedia Asia, Friedrich-Ebert-Stiftung, 2012.

Tempo. "Perang Digital Pilkada Jakarta”, Tempo, edisi 28 November-4 Desember 2016. 